International Journal of Biological Research, $4(1)(2016) 74-77$
International Journal of Biological Research
WPC
Website: $\begin{gathered}\text { www.sciencepubco.com/index.php/IJBR } \\ \text { doi: } 10.14419 / i j b r .44 i 1.6161 \\ \text { Research paper }\end{gathered}$

\title{
Production process and characterization of extra cellular li- pids from bacterial strain from oil industries waste
}

\author{
Vadivel Balamurugan ${ }^{1}$, Veluchamy Balakrishnan ${ }^{2}$, Arjunan Sundaresan ${ }^{1}$ \\ Kodhandapani Vasanthi ${ }^{1}$, Selvaraj Venkatesan ${ }^{1}$ \\ ${ }^{1}$ PG and Research Department of Biotechnology, Sri Vinayaga College of Arts and Science, Ulundurpet-606 107, Tamil Nadu, India \\ ${ }^{2}$ PG and Research Department of Botany, Arignar Anna Government Arts College, Namakkal- 637 002, Tamil Nadu, India \\ *Corresponding author E-mail: balakal78@gmail.com
}

\begin{abstract}
The Bacillus $s p$ was isolated from oil industry waste. The isolated strain was screened for the production of lipase enzyme. The production was done by shake flask fermentation. After downstream processing, the partial purification was done my ammonium sulphate precipitation \& dialysis and the assay was done by photometric method. The various factors affecting production of extra cellular lipase activity was assayed which include $\mathrm{pH}$, different substrate, temperature and additives. Besides, production was made using different carbon source and crude medium. Result showed that $\mathrm{pH} 6$ and $37^{\circ} \mathrm{C}$ is an optimum environmental parameter for the growth of the isolate. In addition, the sucrose was found to be better carbon source.
\end{abstract}

Keywords: Bacillus species; Bacterial strain; Extra cellular lipids; lipase enzyme; Oil industries waste.

\section{Introduction}

Enzymes are nature's catalyst, possessing unique properties that make them highly desirable for their application in processing industry. It is because of their bio-degradability, high specificity and high catalytic efficiency; lipases find prominent position as industrial biocatalysts (Sangeetha et al., 2011). Lipases (triacylglycerol acyl hydrolases, EC 3.1.1.3) catalyze the hydrolysis and the synthesis of esters formed from glycerol and long- chain fatty acids. Lipases occur widely in nature, but only microbial lipases are commercially significant. Microbial lipases are high in demand due to their specificity of reaction, stereo specificity and less energy consumption than conventional methods (Saxena et al., 1999).

Many microorganisms such as bacteria, yeast and fungi are known to secret lipases. Lipase-producing microorganisms have been found in diverse habitats such as industrial wastes, vegetable oil processing factories, dairies, soil contaminated with oil, etc (Sztajer et al., 1998). The oily environment (oil mill effluent) may provide a good environment for isolation of lipase producing microorganisms. Bacterial lipases are mostly extracellular and are greatly influenced by nutritional and physicochemical factors, such as temperature, $\mathrm{pH}$, nitrogen and carbon sources, inorganic salts, agitation and dissolved oxygen concentration (Gupta et al., 2004). Various reports on the different aspects of lipase are available beginning with isolation and screening of lipolytic organisms and optimization of production conditions (Castro-Ochoa et al., 2005). Further screening may leads to isolation of novel lipases which possesses the desired properties. Thus, the study was aimed at isolation, screening and production of lipase from bacterial strain which is derived from oil industries waste.

\section{Materials and methods}

\subsection{Sample collection and isolation of bacteria}

The sample was collected from oil processing industry waste at Chennai in a sterile container and it was brought to the laboratory for further processing. The collected sample was serially diluted up to $10^{7}$ dilutions during sterile saline as a blank and the diluted samples were plated into the sterile nutrient agar plates using spread plate method. The plates were incubated at $37{ }^{\circ} \mathrm{C}$ for 24 hours. The isolated colonies were father purified by streak plate method using sterile nutrient agar medium. The pure cultures were inoculated into sterile nutrient agar slants and nutrient broth for further use.

\subsection{Screening for lipase production}

The isolated bacterial strains were screened for the production of extra cellular lipase using tween agar medium. The pure cultures were streaked at the center of the tween agar plates and the plates were inculpated at $37{ }^{\circ} \mathrm{C}$ for 24 hours. After incubation, observation was made to see the formation precipitation around the bacterial growth. Only one positive and better precipitation formed strain was considered for further study (Rua et al., 1997).

\subsection{Identification of bacteria}

The selected Bacterial strain was subjected into the gram's staining to check the morphology and gram's reaction. The motility was checked up using hanging drop method. The further identification was done using routine Microbiological and Biochemical tests that will be used for identification of bacteria based on the 
key provide by the Bergey's manual of Systematic bacteriology (Bergey et al., 1984).

\section{Lipase enzyme assay}

\subsection{Plate assay}

The plate assay was performed using tween agar plates prepared by excluded with peptone. Around $10 \mathrm{~mm}$ diameter of well was cut out aseptically with the help of cork borer. The well was filled with the culture filtrate and incubated at $35^{\circ} \mathrm{C}$ for overnight. The observation was made to see the precipitation band around the well and the formation of precipitation band was considered as positive result. The negative control was maintained by adding sterile water in the separate well.

\subsection{Chemical assay}

Enzyme assay was done by photometric method using olive oil as a substrate as color developer (Kwon and Ree, 1986).

\subsection{Estimation of total protein}

The chemical assay for the protein content from the sample was determined using Bradford method (Bradford, 1976).

\subsection{Production of lipase using crude substrates}

Various natural oils like Gingili Oil, Coconut oil, Caster oil, ground nut oil and olive were used as substrates for effective enzyme production. The crude oils were collected from oil industries and were sterilized separately. $1 \% \mathrm{v} / \mathrm{v}$ was added with the sterile production basal medium. Then the media were seeded with $2 \%$ inoculums and they were incubated $37^{\circ} \mathrm{C}$ for 48 hours. The amount of total protein and enzyme produced from different substrates were estimated (Kamini et al., 2000).

\section{Partial purification of enzyme}

\subsection{Separation of enzyme}

The enzyme separation from the exhausted medium $85 \% \mathrm{w} / \mathrm{v}$ saturation of Ammonium sulphate saturation (Schuepp et al., 1997). The culture filtrate was saturated with $85 \%$ ammonium suplhate and the mixture was then stored in cold room for 24 hours to precipitate all the proteins. Then the precipitation was separated by centrifugation around $10000 \mathrm{rpm}$ for 10 minutes. Then carefully the supernatant was discarded and the remaining precipitation was dissolved with $5 \mathrm{ml}$ of phosphate buffer $(\mathrm{pH}$ 7.2). The mixture was subjected for dialysis.

\section{Dialysis}

The pretreatment of the dialysis membrane (Sigma) was done by immersing the membrane into the warm phosphate buffer ( $\mathrm{pH} .7 .2)$ for 10 minutes (Schuepp et al., 1997). One end of the membrane tube was closed tightly by fixing the clip. The precipitated protein was then transferred in the dialysis tube and other end was tied with a thread. The pack was suspended freely into a large beaker, which contains around $500 \mathrm{ml}$ of phosphate buffer $(\mathrm{pH} 7)$. The buffer was stirred slowly using magnetic stirrer. The entire setup was placed in the cold room for 48 hours. Every 12 hours the buffer was changed periodically for better dialysis. After dialysis the clip from one end of the membrane was removed and the sample was transferred in to the clean lyophilisation flask.

\section{Results and discussion}

Naturally occurring so many microorganisms are having ability to production the various enzymes. Indeed, it is boon of God because now a days most of the enzymes are industrially important. Lipase is a one of the important enzyme, which can be produced from microorganism.

In this study, the bacterial strains were isolated from oil industry waste dumping because most of the natural wastes are degraded by the native microbes that are growing over those wastes. In such a way, it is fact that the microbes which are isolated from the oil waste dumping may have ability to produce lipase. From the samples, around 5 bacterial strains were isolated. But during screening, it was found that only 2 bacterial strains showed positive results on lipase production. Between two strains, better zone formed bacterial strain was considered for further study.

The identification study showed that the isolated strain has been assigned as bacillus sp based on their biochemical characters. Other than grams reaction and other micro biological biochemical studies, formation of endosperm confirmed the genus of this organism. The result obtained from biochemical characteristics of this strain are shown in table 1.

Table 1: Identification of bacteria

\begin{tabular}{|c|c|c|c|c|c|c|c|c|c|c|c|c|c|c|}
\hline $\begin{array}{l}\dot{0} \\
\dot{z} \\
\dot{s}\end{array}$ & 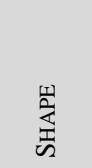 & 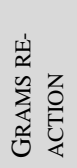 & 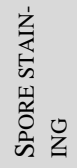 & 突 & 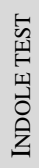 & 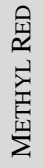 & 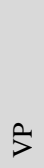 & & 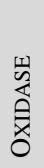 & 告 & 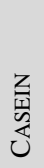 & 孞 & 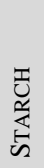 & 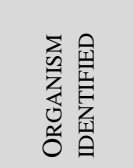 \\
\hline 1 & Bacilli & + & + & + & - & + & - & + & - & + & + & + & - & Bacillus.sp \\
\hline
\end{tabular}

Table 2: Effect of temperature on lipase production

\begin{tabular}{llll}
\hline S.No & Time of Culture withdrawal & Total Protein Content $(\mu \mathrm{g} / \mathrm{ml})$ & Enzyme Activity $(\mathrm{U} / \mathrm{Ml})$ \\
\hline 1 & $6^{\text {th }}$ Hour & $45 \pm 2.28$ & $20 \pm 8.46$ \\
2 & $12^{\text {th }}$ hour & $99 \pm 5.00$ & $23 \pm 2.52$ \\
3 & $18^{\text {th }}$ Hour & $97 \pm 3.87$ & $55 \pm 5.09$ \\
4 & $24^{\text {th }}$ Hour & $90 \pm 3.89$ & $108 \pm 2.00$ \\
5 & $30^{\text {th }}$ Hour & $111 \pm 5.49$ & $138 \pm 2.93$ \\
6 & $36^{\text {th }}$ Hour & $121 \pm 6.89$ & $145 \pm 1.26$ \\
7 & $42^{\text {nd }}$ hour & $137 \pm 2.09$ & $142 \pm 1.73$ \\
8 & $48^{\text {th }}$ Hour & $140 \pm 5.07$ & $165 \pm 2.44$ \\
9 & $54^{\text {th }}$ Hour & $141 \pm 1.54$ & $132 \pm 2.52$ \\
10 & $60^{\text {th }}$ Hour & $143 \pm 1.82$ & $102 \pm 1.73$ \\
11 & $72^{\text {nd }}$ Hour & $139 \pm 3.84$ & $72 \pm 3.16$ \\
\hline
\end{tabular}


Table 3: Effect of temperature on lipase production

\begin{tabular}{llll}
\hline S.No & Temperature $\left({ }^{\circ} \mathrm{c}\right)$ & Total Protein Content $(\mu \mathrm{g} / \mathrm{ml})$ & Enzyme Activity $(\mathrm{U} / \mathrm{Ml})$ \\
\hline 1 & 28 & $85 \pm 2.60$ & $42 \pm 1.54$ \\
2 & 32 & $101 \pm 1.54$ & $114 \pm 1.44$ \\
3 & 37 & $117 \pm 5.09$ & $158 \pm 2.82$ \\
4 & 42 & $107 \pm 2.82$ & $110 \pm 3.16$ \\
5 & 47 & $74 \pm 3.22$ & $45 \pm 3.03$ \\
6 & 52 & $32 \pm 1.09$ & $12 \pm 1.14$ \\
\hline
\end{tabular}

The growth study of the organism is essential for the production of enzyme because most of the extra cellular enzymes are produced during log phase of the organism's growth. Here, the growth study was carried out with slight modification that samples were collected activity. In the growth study, we found only minimum production was observed till $12^{\text {th }}$ hour of its growth. It indicates that the organism should have in the lag phase of growth. But the gradual increasing production was observed from $18^{\text {th }}$ hour and maximum production was found till $60^{\text {th }}$ hour, so the strain should have maintained a long log phase from around $18^{\text {th }}$ hour to $54^{\text {th }}$ hours approximately. Most of the mesophilic bacteria are maintaining $\log$ phase from $8^{\text {th }}$ hour to $36^{\text {th }}$ hour (Saeed et al., 2005) of its growth. This variation of log phase timing is based on the nutrient present in the MS-medium and the cultural condition of the organism. The environmental parameter also influencing the maintenance time of the Bacteria (Dutta et al., 2005). Interestingly in contrast, come Gram-negative bacteria like Pseudomonas sp show the same kind of growth time like Bacillus sp (Noureddini et al., 2005).

Infect that the extra cellular enzymes are produced during log phase but within the log phase the production may be vary. The result revealed that the higher production has occurred during $42^{\text {nd }}$ hour than initial and middle log phase timing from $24^{\text {th }}$ hour to 42 hour respectively. Around $165 \mathrm{U} / \mathrm{ml}$ of enzyme has produced at $48^{\text {th }}$ hour and $145 \mathrm{U} / \mathrm{ml}$ and $142 \mathrm{U} / \mathrm{ml}$ have been produced during $36^{\text {th }}$ hour and $42^{\text {nd }}$ hour respectively.

The environmental parameters are showing great influence in the growth of organisms and production of enzymes. The main parameters like temperature, $\mathrm{pH}$ are very essential parameters that are influence the production of lipase. To optimize the optimum temperature for the better production, productions were made in various temperatures. Like other mesophilic organisms, the isolated Bacillus strain also needed the $37^{\circ} \mathrm{C}$ and almost equal amount of enzyme has produced at $42{ }^{\circ} \mathrm{C}$ and $32{ }^{\circ} \mathrm{C}$. These results show the temperature requirement for this isolate is ranging from $32{ }^{\circ} \mathrm{C}$ to $42{ }^{\circ} \mathrm{C}$. Generally the temperature requirement for microorganisms is the based on the environment where it is isolated and the organisms will show the higher growth and higher production in this temperature. Besides the enzymes and other bio logical compounds which are produced by this temperature. The production of lipase from different temperature has been already reported by several enzymologists. The lipase has been produced form the range of temperatures from $25{ }^{\circ} \mathrm{C}$ to $40{ }^{\circ} \mathrm{C}$ from the bacterial strain Pseudomonas fragi (Schueppet al., 1997). In contrast, the lipase has been produced from Psychotropic bacteria Serration marcescens at $25{ }^{\circ} \mathrm{C}$ (Adham, 2003).

The optimal $\mathrm{pH}$ for lipase production was determined to be around $\mathrm{pH} 6.0$ (table 4). This distinctive property of high $\mathrm{pH}$ optimum is a common feature among all lipases and the commercially available lipase from Bacillus sp. The lipase was very stable over a broad $\mathrm{pH}$ range from 5 to 9 after incubation for 36 hour, indicating its potential for practical use in industrial purpose which requires stability over wide $\mathrm{pH}$ ranges. In this study, the $\mathrm{pH}$ maximized lipase production is similar to the results reported by previous investigators (Adham, 2003). In contrast, maximum production of lipase by strain of Bacillus sp. was reported at $\mathrm{pH} 8$ by Secades et al., (2001).
Table 4: Effect of $\mathrm{pH}$ on total protein and enzyme production

\begin{tabular}{llll}
\hline S.No & $\mathrm{pH}$ & $\begin{array}{l}\text { Total Protein Content } \\
(\mu \mathrm{g} / \mathrm{ml})\end{array}$ & $\begin{array}{l}\text { Enzyme Activity } \\
(\mathrm{U} / \mathrm{Ml})\end{array}$ \\
\hline 1 & 5 & $139 \pm 3.43$ & $134 \pm 3.40$ \\
2 & 6 & $171 \pm 2.19$ & $177 \pm 2.19$ \\
3 & 7 & $152 \pm 1.71$ & $148 \pm 2.44$ \\
4 & 8 & $148 \pm 1.43$ & $96 \pm 1.78$ \\
5 & 9 & $132 \pm 1.41$ & $48 \pm 2.28$ \\
\hline
\end{tabular}

Besides, the addition of carbon source, such as mannitol and glucose to the principal medium has yielded optimum production. But sucrose was found to be an effective carbon source for the production of lipase from Bacillus strains because the isolate has yielded higher amount of $(178 \mathrm{U} / \mathrm{ml})$ lipase while compared with the other sugars (table 5). However, considerable amount of enzyme has been produced with other carbon sources too. In contrast, high enzyme activity has been exhibited using olive oil as a carbon source (Valeria et al., 2003).

Table 5: Effect of different carbon sources on lipase production

\begin{tabular}{llll}
\hline S.No & Carbon Source & $\begin{array}{l}\text { Total Protein Content } \\
(\mu \mathrm{g} / \mathrm{ml})\end{array}$ & $\begin{array}{l}\text { Enzyme Activity } \\
(\mathrm{U} / \mathrm{Ml})\end{array}$ \\
\hline 1 & Glucose & $170 \pm 2.82$ & $163 \pm 6.16$ \\
2 & Sucrose & $198 \pm 5.07$ & $178 \pm 1.67$ \\
3 & Manito & $182 \pm 1.07$ & $150 \pm 5.09$ \\
4 & Sorbitol & $101 \pm 5.09$ & $113 \pm 5.49$ \\
5 & Maltose & $81 \pm 8.02$ & $87 \pm 4.47$ \\
6 & Lactose & $171 \pm 2.60$ & $23 \pm 3.06$ \\
7 & Mannose & $72 \pm 3.74$ & $19 \pm 1.41$ \\
8 & Arabinose & $63 \pm 2.79$ & $12 \pm 2.44$ \\
9 & Xylose & $28 \pm 1.41$ & $13 \pm 2.00$ \\
10 & Galactose & $92 \pm 3.16$ & $76 \pm 2.72$ \\
\hline
\end{tabular}

The nitrogen sources are of secondary energy sources for the organisms which play an important role in the growth of the organism and the production. The nature of the compound and the concentration which we are using may stimulate or down modulate the production of enzyme in the medium amended with casein and comparable amount of enzyme has been produced with the medium amended with Urea, ammonium nitrate (table 6). In contrast, negligible amount has been produced with beef extract. Even though, the beef extract is alternate for yeast extract for most of the bacterial growth, as for as lipase production concern, they are showing different effect (Valeria et al., 2003).

The real and beneficial production of enzyme is produced from the natural sources and industrial wastes. In this study, several natural and industrial wastes were used as substrates. The results revealed that the maximum production was observed in olive oil (table6). Some evidence showed that the almond meal is the best crude medium for the higher production of lipase by Bacillus sp (Ikramul-haq et al., 2001). Almond meal provides all required carbon, nitrogen and contained sucrose, gum, asparagines and proteins.

This result shows clearly various factors affecting production of extra cellular lipase activity was assayed which include $\mathrm{pH}$, different substrate, temperature and additives. Besides, production was made using different carbon source and crude medium. Result showed that $\mathrm{pH} 6$ and $37{ }^{\circ} \mathrm{C}$ is an optimum environmental parameter for the growth of the isolate. In addition, the sucrose was found to be better carbon source 
Table 6: Effect of different nitrogen sources on enzyme production

\begin{tabular}{llll}
\hline S.No & $\begin{array}{l}\text { Name of the Nitrogen } \\
\text { Sources }\end{array}$ & $\begin{array}{l}\text { Total Protein Con- } \\
\text { tent }(\mu \mathrm{g} / \mathrm{ml})\end{array}$ & $\begin{array}{l}\text { Enzyme Activi- } \\
\text { ty }(\mathrm{U} / \mathrm{Ml})\end{array}$ \\
\hline 1 & Yeast Extract & $191 \pm 4.19$ & $115 \pm 2.60$ \\
2 & Casein & $212 \pm 2.60$ & $155 \pm 2.28$ \\
3 & Gelatin & $206 \pm 4.26$ & $65 \pm 2.75$ \\
4 & Beef Extract & $198 \pm 3.74$ & $16 \pm 3.19$ \\
5 & Urea & $99 \pm 2.86$ & $120 \pm 2.64$ \\
6 & Potassium Nitrate & $101 \pm 2.09$ & $100 \pm 2.60$ \\
7 & Ammonium Nitrate & $119 \pm 3.57$ & $140 \pm 2.28$ \\
\hline
\end{tabular}

Table 7: Lipase production from various crude substrates

\begin{tabular}{llll}
\hline S.No & $\begin{array}{l}\text { Name of the Sub- } \\
\text { strates }\end{array}$ & $\begin{array}{l}\text { Total Protein } \\
\text { Content } \\
(\mu \mathrm{g} / \mathrm{ml})\end{array}$ & $\begin{array}{l}\text { Enzyme Activity } \\
(\mathrm{U} / \mathrm{Ml})\end{array}$ \\
\hline 1 & Gingili Oil & $89 \pm 2.09$ & $34 \pm 3.52$ \\
2 & Coconut Oil & $92 \pm 2.82$ & $64 \pm 2.44$ \\
3 & Groundnut Oil & $98 \pm 1.41$ & $85 \pm 4.04$ \\
4 & Olive Oil & $115 \pm 2.04$ & $135 \pm 4.44$ \\
5 & Caster Oil & $86 \pm 2.09$ & $74 \pm 2.60$ \\
\hline
\end{tabular}

\section{References}

[1] Adham SA, Rodríguez S, Ramos A, Santamaría RI, Gil JA.Improved vectors for transcriptional/translational signal screening in corynebacteria using the melC operon from Streptomyces glaucescens as reporter.Arch Microbiol. 2003; 180 (1):53-9. http://dx.doi.org/10.1007/s00203-003-0560-5.

[2] Bergey D H, Breed R S, Murray E G D, Hitchens A P. Bergey's manual of determinative bacteriology, abridged $5^{\text {th }}$ ed. Geneva, N.Y: Biotech Publications; 1984. p. 76 http://dx.doi.org/10.1016/0003-2697(76)90527-3.

[3] Bradford MM.A rapid and sensitive method for the quantitation of microgram quantities of protein utilizing the principle of proteindye binding.Anal Biochem.1976; 72:248-54.

[4] Castro-Ochoa, L.D., C. Rodriguez-Gomez, G. Valerio-Alfaro and R.O. Ros, 2005.Screening, purification and characterization of the thermoalkalophilic lipase produced by Bacillus thermoleovorans CCR11.Enzyme Microb. Technol., 37: 648-654. http://dx.doi.org/10.1016/j.enzmictec.2005.06.003.

[5] Dutta JR,Dutta PK, Banerjee R. Modeling and optimization of protease production by a newly isolated Pseudomonas sp. using a genetic algorithm. Process biochemistry. 2005; 40 (2): 879-884 http://dx.doi.org/10.1016/j.procbio.2004.02.013.

[6] Gupta R, Gupta N, Rathi P. Bacterial lipases: an overview of production, purification and biotechnological properties. ApplMicrobiolBiotechnol 2004; 64: 763-781. http://dx.doi.org/10.1007/s00253004-1568-8.

[7] Ikram-Ul-Haq, KiranShahzadi, UzmaHameed, Muhammad MohsinJaved and Qadeer,M.A., 2006. Solid state fermentation of cellulases by locally isolated Trichodermaharzianum for the exploitation of agricultural by products. Pakistan journal of biological Sciences 9 (9): 1779-1782.

[8] Kamini NR, Fujii T, Kurosu T,Iefuji H. Production, purification and characterization of an extra cellular lipase from the yeast, Cryptococcus sp. S-2. Process biochemistry. 2000; 36: 317-324. http://dx.doi.org/10.1016/S0032-9592(00)00228-4.

[9] Kwon DY,Ree JS. A simple and rapid colorimetric method for the determination of free fatty acids for lipase assay.Journal of the American Oil Chemists' Society.1986; 63: 89-92. http://dx.doi.org/10.1007/BF02676129.

[10] Noureddini H, Gao X, Philkana RS.Immobilized Pseudomonas cepacia lipase for biodiesel fuel production from soybean $\begin{array}{lllll}\text { oil.Bioresour } \quad \text { Technol. 2005; } 96 & 96 & \text { (7):769-77. }\end{array}$ http://dx.doi.org/10.1016/j.biortech.2004.05.029.

[11] Rúa ML, Schmidt-Dannert C, Wahl S, Sprauer A, Schmid RD.Thermoalkalophilic lipase of Bacillus thermocatenulatus largescale production, purification and properties: aggregation behaviour and its effect on activity.J Biotechnol. 1997; 56 (2):89-102.

[12] Saeed HM, Zaghloul TI, Khalil AI, Abdelbaeth MT.Purification and characterization of two extracellular lipases from Pseudomonas aeruginosa Ps-x.Pol J Microbiol. 2005; 54 (3):233-40.

[13] Sangeetha R,Arulpandi I,Geetha A. Bacterial lipases as potentia industrial biocatalysts: An overview. Research Journal of Microbiology.2011; 6: 1-24. http://dx.doi.org/10.3923/jm.2011.1.24.

[14] Saxena RK, Ghosh PK, Gupta R, Davinson WS, Bradoo .S, Gulati R. Potential biocatalysis and future industry.CurrSci 1999: 77: 110115.
[15] Schuepp C, Kermasha K,MichalskiM.-C, Morin A. Production, Partial Purification and Characterization of Lipasesfrom Pseudomonas fragi CRDA 037.Process Biochem.1997; 32: 225-232. http://dx.doi.org/10.1016/S0032-9592(96)00065-9.

[16] Secades P, Alvarez B,Guijarro JA. Purification and characterization of a psychrophilic, calcium-induced, growth-phase-dependent metalloprotease from the fish pathogen Flavobacteriumpsychrophilum.Appl Environ. Microbiol.2001; 67(6):2436-2444. http://dx.doi.org/10.1128/AEM.67.6.2436-2444.2001.

[17] Sztajer H, Maliszewska I, Wieczorek J. Production of exogenous lipase by bacteria, fungi and actinomycetes. Enzyme MicrobTechnol 1998; 10: 492-7. $\quad$ http://dx.doi.org/10.1016/0141 0229(88)90027-0.

[18] Valeria MG, Lima-Nadia K, Maria-Inez M, Sarquis-David A, Mitchell-Luiz P and Ramos-Jose D. Production of Lipase by Penicilliumaurantiogriseum. Food Technol. Biotechnol. 2003; 41, 105110 